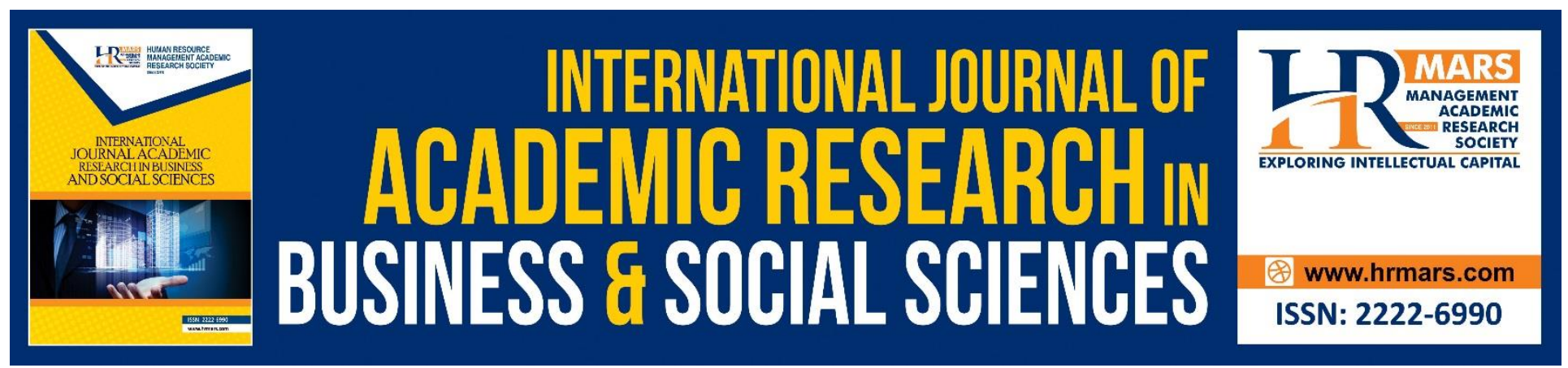

\title{
Human Resources Challenges and Their Impact on the Preservation of Human Capital: Field Study in Private Hospitals in Irbid Governorate - (Jordan)
}

Shaima Alalawneh

Faisl Bourini

To Link this Article: http://dx.doi.org/10.6007/IJARBSS/v9-i3/5748

DOI: $\quad 10.6007 /$ IJARBSS/v9-i3/5748

Received: 12 Feb 2019, Revised: 28 Feb 2019, Accepted: 28 March 2019

Published Online: 30 March 2019

In-Text Citation: (Alalawneh \& Bourini, 2019)

To Cite this Article: Alalawneh, S., \& Bourini, F. (2019). Human Resources Challenges and Their Impact on the Preservation of Human Capital: Field Study in Private Hospitals in Irbid Governorate - (Jordan). International Journal of Academic Research in Business and Social Sciences, 9(3), 815-827.

\section{Copyright: (C) 2019 The Author(s)}

Published by Human Resource Management Academic Research Society (www.hrmars.com)

This article is published under the Creative Commons Attribution (CC BY 4.0) license. Anyone may reproduce, distribute, translate and create derivative works of this article (for both commercial and non-commercial purposes), subject to full attribution to the original publication and authors. The full terms of this license may be seen at: http://creativecommons.org/licences/by/4.0/legalcode

\section{Vol. 9, No. 3, 2019, Pg. 815 - 827}

Full Terms \& Conditions of access and use can be found at http://hrmars.com/index.php/pages/detail/publication-ethics 


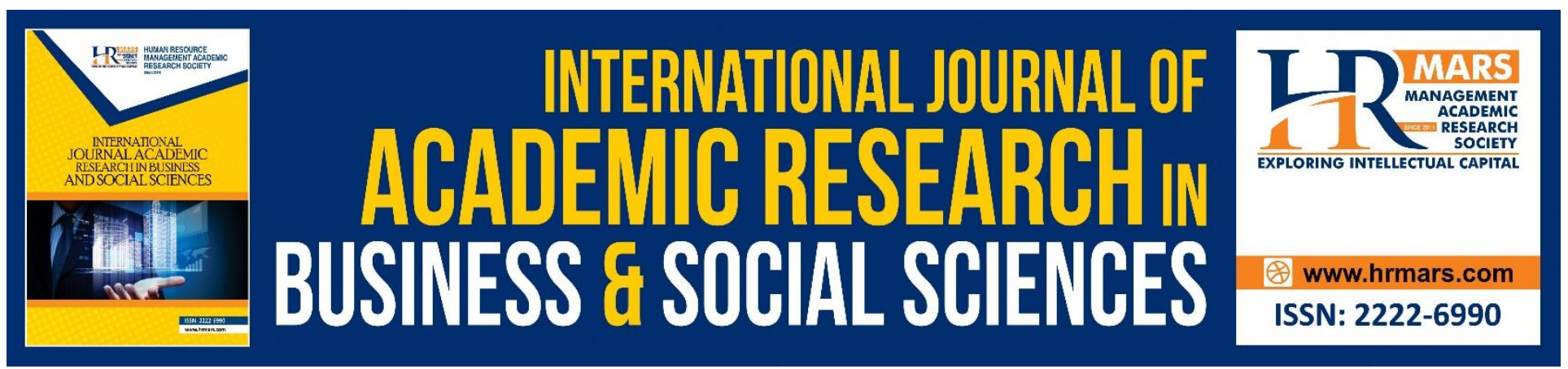

\title{
Human Resources Challenges and Their Impact on the Preservation of Human Capital: Field Study in Private Hospitals in Irbid Governorate - (Jordan)
}

\author{
Shaima Alalawneh \\ Jadara University \\ Email: shaymaa_al3lawneh@hotmail.com \\ Dr. Faisl Bourini \\ Jadara University \\ Email: Faisl.bourini@yahoo.com
}

\begin{abstract}
This study aims to identify the challenges facing human resources and their impact on the preservation of human capital in the private hospitals of the governorate of Irbid. To achieve the goal of this study, the researchers developed a questionnaire, that was distributed to the study sample, consisting of (200) people, randomly selected, from the study population of (600) people. The result of this study showed a statistically significant impact on human resource that face challenges in preserving human capital in the private hospitals of Irbid's Governorate. The study recommended addressing the challenges facing human resources through increased wages, incentives, rewards, comprehensive health insurance, providing an appropriate work environment and ideal administrative leadership that will lead to career stability Thus; achieving the competitiveness of the hospital.
\end{abstract}

Keywords: Challenges facing Human Resources, Incentives, Work Stress, Administrative Leadership, Human Capital, Private Hospitals, Jordan

\section{Introduction}

Human resources are among the most important assets in the organization that lead to goal reaching, competitive advantage, survival and continuation of the organization in the labor market, Due to its importance, there is an intense competition in the developed organizations and the global market, organizations are striving to preserve their human resources especially in light of the many continuous changes of the 21st century. 
INTERNATIONAL JOURNAL OF ACADEMIC RESEARCH IN BUSINESS AND SOCIAL SCIENCES

Vol. 9, No. 3, March, 2019, E-ISSN: 222 2-6990 @ 2019 HRMARS

Human capital has an important role to play in the service of economic and social development and it is also used to link the lack of natural and human resources that organizations suffer from. Interest in human capital increased after the international trend of globalization, and therefore most countries of the world devoted enormous sums to develop and improve the characteristics of human capital to meet the requirements of economic and social development (AlRubaawi \& Abbas, 2015). Distinguished human resources are the real power and an effective tool to achieve organizational goals. Management provides training opportunities to increase skills and abilities to improve performance and decision-making (Hassan, 2009; Irtaimeh et al, 2016). The Organization is considered the tool for achieving objectives, development and change, and they are the basis for the operation of the organization's material resources (Salmi, 2008).

The perception of human resources in organizations has changed from being a cost element to an asset of an organization that can be invested. This change makes human resources one of the most important resources of an organization. When an organization obtains human resources with knowledge, experience and skills, it has a stock of human resources Thus; skills, trends and knowledge that are an important component of this stock to achieve its organizational goals and objectives (Hassan, 2005; Abualoush et al, 2018). As a result, human resources have become the primary focus of attention on the world that will create profit and excellence focusing on efficient human resources, outstanding skills and capabilities. If all possibilities are available, human resource is the only one that has the potential to succeed and exploit these possibilities. (Gad Al rab, 2005).

In recent times, the challenges facing human resources have increased, and based on the importance of human resources, the challenges should be met, followed wisely, and without confusion, in order to maintain highly qualified staff within the organization. This study is intended to identify the most important challenges facing human resources, their impact on preserving human capital in private hospitals in Irbid governorate, doctors, nurses, and technicians.

Human resources management is one of the major organizational factors affecting human capital at the organizational level (Katou,2017). Human resources management practices play an important role in influencing human capital, so the study of the impact of such practices as training, incentives and promotions has received considerable attention By researchers in the Jordanian business environment (Aladwan, 2015; Obeidat, 2012); however, one of the most challenging challenges facing organizations, especially in their human resources, is their ability to maintain staff with high skills and experience that drives their human capital to stay or leave the organization (obeidat \& Otibi , 2015) , This study focus on the challenges facing human resources management in human capital development and conservation, It is one of the few studies that focused on the challenges that prevent the continuation or departure of the human capital of the organization and in the health sector (private hospitals in Irbid), in particular, which leaves the human capital trained and highly skilled especially in doctors and nurses, Identifying the challenges of human resources management practices that face human capital will make it easier for organizations to address those challenges that affect the survival or departure of human capital in organizations. Based on the importance of human resources, challenges must be met, and cope with wisdom, and without confusion, In order to maintain the highly qualified staff within the Organization. Furthermore, human resources practices in any organization are highly interrelated and cannot be interpreted as independent factors. In this study, some challenges to human resources management were collected 
and their impact on human capital conservation was examined. In view of the high demand for doctors and nurses with high skills and experience who have access to other jobs, which involves loss of human capital to the Organization, this study was designed to focus on the challenges of HR management such as incentives, work pressures, and management leadership.

The purpose of this study seeks to achieve job stability by reducing the cases of voluntary leave.

\section{Literature Review}

\section{Challenges of Human Resources}

Human Resources defined as all individuals involved in the development, formulation of policies, objectives, activities, and completion of business in an institution (Baloot, 2002). It was also defined as a set of practices, policies related to selection, employment of human resources, and the differentiation between them (Dissler, 2003). It is also known as the system that helps organize individuals to deal with each other, contributing to their self-realization, and optimizing their potential for maximum productivity(Barkawi, 2013). Human capital is considered the most important element of intellectual capital since the whole continuation of the organization counts on it, Human Capital (HC) can be defined as "the sum of employees' competence, knowledge, skills, innovativeness, attitude, commitment, wisdom and experience" (obeidat et al.,2017).

It has been pointed out that challenges are those things when present or not, constitute a permanent or temporary threat, in whole or in part, to a situation that is desirable to continue or that stems from different local, regional and international environments such as problems, obstacles, changes, developments and difficulties (Mutahar, 2005). Several studies have pointed out that the challenges facing human resources, including the study of ( Al-Ubaidi, 2010) which considered the problems faced by each of the workers in their daily working life as follows: wage, training, distribution of workers, housing and transportation and also the work relationship.

The study of Tuwaijri (2007) pointed to the problems facing the practice of nursing in the working environment as follows: the problem of poor educational level and awareness, the difficulty of the profession, the high pressures of work, weak physical and moral incentives, lack of flexibility in work and weak leadership, the absence of standards, weak cooperation and participation, weak physical environment and supporting services. Based on the information obtained from researchers from some private hospitals in Irbid, the researchers would like to study the main challenges of incentives, work pressures and administrative leadership.

\section{Incentives}

Hassan (2008) notes the benefits and importance of the incentive system for the individual. The organization increases the individual's sense of justice and satisfaction, as it satisfies their needs as well as attracting the best competencies to work within the organization and earning the loyalty of the employees and satisfying their desires and material and moral needs which improve the reputation of the organization among them. ( Al-Kaabi \& Saleh ,2004; Obeidat et al , 2018) believe that the incentive system in an organization has two objectives: first; the economic objective which is beneficial to individuals and an organization using elements of production, and a better use as well as the increased productivity. Second; the moral goal in which creates the right atmosphere for the individual to work more enthusiastically to satisfy his needs and desires. 


\section{Work Pressure}

Work pressure is defined as an adaptive response that affects the characteristics of the person, this response is the result of external factors, thus factors may be psychological or physical (Harem, 2013). the National Institute of Health and Safety (NIOSH) defined work pressure as the psychological and physical painthat is felt by an individual; if the functional requirements are not suited to his needs and abilities at work(Al-Khatatna, 2011).

The causes of work stress vary in regulatory, external, and personal factors. Pressure sources overlaps within each other and effects the individuals in the work environment (Al-Humian, 2007). The internal sources of work pressure include workload, ambiguity of role (Harem, 2013), supervision pattern(Al-Khatatna, 2011), and individual role conflict (Abd al-Baqi, 2004). While the external elements of work pressure include; stimuli (Hamzawi, 2007), responses (altweim,2005), and interaction(abd-albaqei,2004).

\section{Administrative Leadership}

Administrative leadership is not a talent, it is based on principles and basics that the manager must be familiar with, so that he becomes an influential leader over others and can change their behavior. Leadership is also a set of interactions between the individual and his group (Rida, 2010). The importance of leadership comes from the importance of the human elements, which has become the most important resource of an organization which achieves the goals since individuals differ in their behavior. The behavior of an individual is difficult to control due to the volatility in one's feelings. In order to benefit from the efforts and competencies of individuals to reach a desired goal; a strong and effective management leadership must be provided that has the ability to influence the behavior of individuals and encourage them to achieve a high level of performance. Therefore, training programs should be provided to improve the leadership level of managers. A successful leader can create an atmosphere of innovation and creativity among subordinates due to the ability of the leader to influence their behavior. (Bohz \& Merzouki, 2009).

\section{Maintaining Human Capital}

The United Nation Development Programmed (UNDP) defines human capital as every addition to employee's productivity which results from the skills and techniques that they have acquired by experience. Human capital is different from physical capital since it is intangible and indescribable (UNDP, 2003). Ashton (2005), believes that human capital is the skills, experience, accumulated knowledge of staff, ability to deal with risk, problem solving and decision making which reflects the organization's ability to manage its resources to achieve competitive advantage(Malkawi, et al, 2017)

FAO is the foundation of innovation, and human capital is also a source of influence on the performance of organizations through the organization's rich human capital, skills and knowledge that are competitive, evolving and growing.

(Al-Ma'ani et al., 2011) believe that the importance of human capital helps create innovation and a variety of new knowledge used in the development of the organizations. Human capital is difficult to imitate because it is a scarce resource and therefore it must be maintained, developed and taken care of. It plays a bigrole in achieving competitive advantage. Human capital is also a source of 
influence on the performance of organizations through the organization's rich human capital, skills, knowledge that are competitive, developing and growing.

There are many ways to preserve human capital within organizations and prevent their infiltration into other organizations, such as achieving job satisfaction, raising morale among employees, working diligence, non-absenteeism, etc. In this research, we will study the aspects of job satisfaction. Many researchers have engaged the issue of job stability and the organization's preservation of its human resources with the factors of job satisfaction. Job stability cannot occur without the satisfaction of the worker, with all that surrounds him within the institution in which he works (Al-Fateh,2006). Job satisfaction is a state of joy and pleasure felt by the individual when reaching goals and benefits (Bhansi, 2011). Job satisfaction was also referred to as an attention to the various physical, environmental and psychological conditions that led to the attainment of conditions for which the individual was satisfied (Sultan, 2003).

\section{Challenges Facing Human Resources and the Preservation of Human Capital}

In this study, the researchers investigated the challenges facing human resources and the three resources were studied are: incentives, work pressures, administrative leadership and their impact on the preservation of human capital. Incentives have a strong relationship to the preservation of human resources in business organizations. The more salaries and incentives are appropriate to the amount of work, the more the employee is functionally satisfied and therefore not thinking about moving to another organization (Halawani, 2001). While work pressures may result in an employee leaving his job as a way of escaping this pressure which indicates an incompatibility between the individual and the organization and in some cases, this escape may be a psychological step.

A wise leadership is capable of creating the right atmosphere to motivate employees to continue their work, but if leadership has a negative role, it will not be able to sustain its employees (Harbi, 2008). Some studies have shown that the leader who is interested in developing a relationship between him and his subordinates has a clear impact on their job satisfaction which leads to continued work and retention. While a leader who focuses on work and neglects his workers will reflect negatively on their level of satisfaction and create a negative view of that leader (Safhi, 2011). And since a leader communicates directly with his subordinates, his style must affect the feelings of workers and work process. The working environment which suffers from strong control, bullying and lack of freedom, will lead to a decrease in the desire to work and increase pressure (Al-Dosari, 2013).

\section{Research Methodology}

An analytical descriptive approach was used for this study "the method of studying, dealing with an event, phenomenon or an issue" is the possibility of obtaining information that helps in answering the research questions without any intervention from the researchers. It also depends on studying the phenomenon as it is in fact describing it, then the analysis of its data and the relationship between its components, which is found between the independent variable "challenges to human resources" and the dependent variable "preserving human capital" in an attempt to identify the effect of the independent variable on the dependent variable to reach a conclusion and to contribute to the development and improvement of the status. The population of the study includes doctors, 
nurses and technicians working in private hospitals in the governorate of Irbid which consistsof600 employees, being the random sample of the study community. (220) questionnaires were distributed by hand, of which 205 questionnaires were returned, and only 200 of them are valid for analysis.

\section{Research Model}

The model of the study is based on the following studies; (Al-Dossari, Husain Al-Marhi 2013), leadership styles and their relation to job satisfaction at the College of Technology in Al-Kharj a point of view of employees. Master Thesis, Naif Arab University for Security Sciences, Riyadh. Tamasini, Munira (2015), The Relationship of Work Stress to Job Satisfaction, Unpublished Master Thesis, AlShaheed University Hama Lokhdar Al-Wadi. Al-Tuwaijri, Bahia Ibrahim Al-Tuwaijri (2007); Problems Facing Practitioners of Nursing in the Work Environment, Thesis Unpublished, King Saud University, Riyadh.al-taijani,yousef, al-hassan, mohammed (2008) incentives and impact on job satisfaction, master thesis, Arab British academy for higher education.

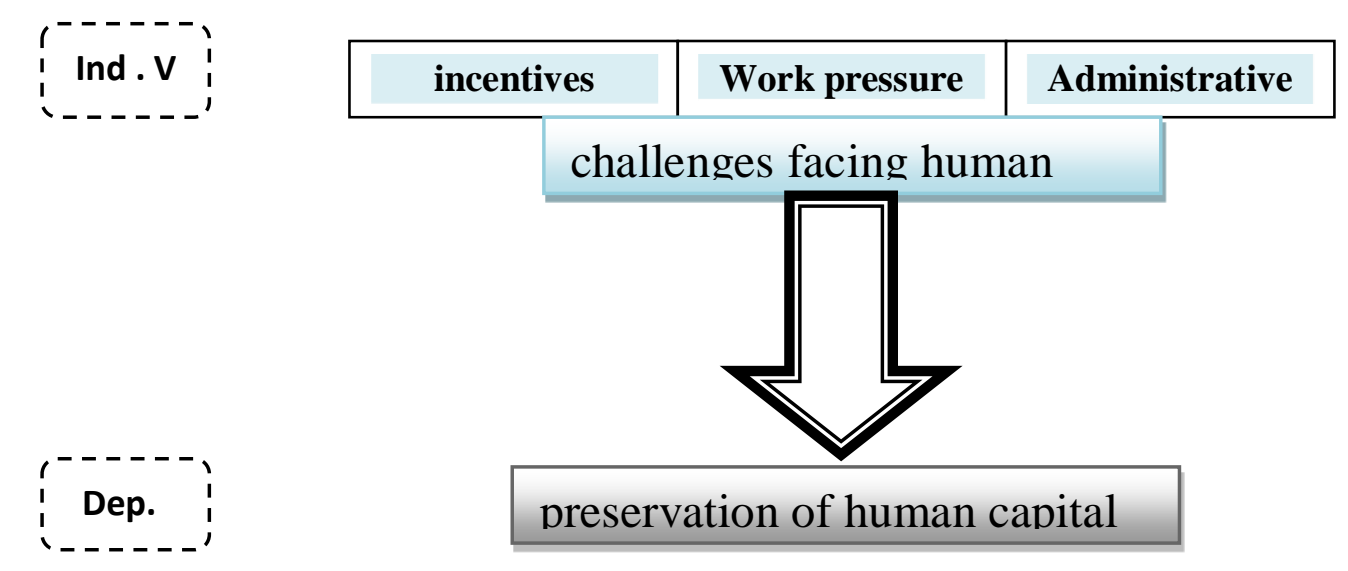

\section{Research Hypotheses}

There is no statistically significant impact at level of significance $(a \leq 0.05)$ for the challenges facing human resources in maintaining human capital in the private hospitals of Irbid.

\section{Data Analysis and Results}

In order to investigate the relationship between two independent variables (challenges facing human resources) and one dependent variable (maintaining human capital), in which these variables have been measured using 5-points Likert scale that varies between not applied at all = 1 to totally applied $=5$; reliability and validity analyses was conducted, descriptive analysis was used to describe the characteristic of sample and the respondent to the questionnaires besides the independent and dependent variables. Also, multiple regression analysis was employed to test the research hypotheses. 


\section{Reliability and Validity}

To verify the validity of the study tool, the questionnaire was presented to specialist and experience of the faculty members in the administrative departments in the economics colleges of the following universities (Jadra, Yarmouk, Applied Sciences, Petra) to judge their validity. The Kronbach Alpha coefficient was used for internal consistency. The value of Kronbach Alpha (0.94) was considered a good percentage for the purpose of generalizing the results of the study. The current ratio is disseminating the results of such studies which are (0.60) (alshareefen and Kilani, 2007), and Table 1 shows the consistency of the variables of the study transactions.

Table (1): Stability coefficients (Cronbach alpha) for all the subjects of the study fields and the instrument as a whole

\begin{tabular}{|l|l|}
\hline Variables & Cronbach Alpha \\
\hline challenges facing human resources & 0.82 \\
\hline preservation of human capital & 0.92 \\
\hline All & 0.94 \\
\hline
\end{tabular}

\section{Descriptive Analysis}

In order to describe the responses and thus the attitude of the respondents toward each question they were asked in the survey, the mean and the standard deviation were estimated. While the mean shows the central tendency of the data, the standard deviation measures the dispersion which offers an index of the spread or variability in the data (Sekaran, 2013). In other words, a small standard deviation for a set of values reveals that these values are clustered closely about the mean or located close to it; a large standard deviation indicates the opposite. The level of each item was determined by the following formula: (highest point in Likert scale - lowest point in Likert scale) / the number of the levels used $=(5-1) / 3=1.33$, where 1-2.33 reflected by "Low", 2.34-3.67 reflected by "moderate" and 3.68-5 reflected by "high". Then the items were being ordered based on their means. Tables (2) and (3) show the results.

Table (2) The arithmetical averages and standard deviations of respondents' responses to the dimensions of the "challenges to human resources" axis in descending order

\begin{tabular}{|l|l|l|l|l|l|}
\hline Order & $\#$ & dimension & Mean & SD & Level \\
\hline 1 & 1 & incentives & 2.63 & 0.46 & Moderate \\
\hline 2 & 2 & Work pressure & 2.58 & 0.32 & Moderate \\
\hline 3 & 3 & Administrative Leadership & 2.51 & 0.39 & Moderate \\
\hline \multicolumn{2}{|l|}{ challenges facing human resources } & 2.56 & 0.31 & Moderate \\
\hline
\end{tabular}

Table 2 shows that the mean of the responses of the sample members on the dimensions of the HR challenge axis ranged between 2.51-2.63 with an average rating of all dimensions, followed by "incentives" with an average of 2.63 , The second rank came after "work pressure" with an average of (2.58). the third and final rank "administrative leadership" came with an average of 2.51. The mean of the challenges of human resources reached 2.56 with average rating. The level of awareness in private hospitals is important to reduce resource challenges. The results can be explained by an acceptable level of management interest in hospitals for the career planning of their staff, including 
INTERNATIONAL JOURNAL OF ACADEMIC RESEARCH IN BUSINESS AND SOCIAL SCIENCES Vol. 9, No. 3, March, 2019, E-ISSN: 222 2-6990 @ 2019 HRMARS

the identification of training, transport, promotion, planning and career development activities for their staff. private hospitals are trying to find out why employers are left work, or stay or satisfied with their work. Private hospitals consider their human resources as the most important factor in the production process. Health service is characterized by fully relying on the forefront; the recipient of the service cannot be separated from the quality of service from the forefront.

Table (4): The mean and the standard deviations of respondents' responses to the paragraphs of the "Maintaining Human Capital"

\begin{tabular}{|l|l|l|l|}
\hline Dimension & Mean & SD & Level \\
\hline preservation of human capital & 2.48 & 0.36 & Moderate \\
\hline
\end{tabular}

Table 4 shows that the statistical averages of respondents' responses to the paragraphs of the "Maintaining Human Capital" that ranged between (1.80-2.93). This is due to the fact that private hospitals do not take the necessary measures in maintaining human capital career, the employees' knowledge and skills, provide incentives and rewards.

\section{Hypothesis Testing Results}

The hypothesis of the study: There is no statistically significant effect at the level of significance (a.0.05) of the challenges that facing human resources in maintaining human capital.

In order to verify the validity of this hypothesis, the multiple regression equation was applied, the results of which showed that the value of the total correlation coefficient, which is the ratio of the independent variables combined with the dependent variable $(R)$, was 0.96 , which is statistically significant. The challenges of human resources and the preservation of human capital as a whole, and the value of (R-square) (0.92), which accounts for $92 \%$ of the differences in the values of the dependent variable, while (8\%) of the differences are caused by factors Others, which have not been taken into account in this model, as shown in Table (12) that the most variables Independent management has a significant influence on the preservation of human capital. Administrative leadership was the highest (0.55) for administrative leadership (0.44) and for work pressure (0.02). Table 5: Multi regression results, the impact of human resources challenges in maintaining human capital

\begin{tabular}{|l|c|c|c|c|c|c|}
\hline \multicolumn{1}{|c|}{ Independent Variables } & $(\beta)$ & Std. err & $(R)$ & $\left(R^{2}\right)$ & $(F)$ & Sig \\
\cline { 1 - 3 } incentives & 0.44 & 0.028 & & & & \\
\cline { 1 - 3 } Work pressure & 0.02 & 0.025 & 0.96 & 0.92 & 732.21 & 0.00 \\
\cline { 1 - 3 } & 0.55 & 0.034 & & & \\
\hline
\end{tabular}

Statistically significant at $\alpha(0.05)$

The hypothesis is a statistically significant effect at the level of (a0.05) of the challenges that facing human resources in preserving human capital in private hospitals in Irbid governorate. 


\section{Discussion and Conclusions}

This study aimed to investigate the impact of the challenges facing human resources (labor pressures, incentives, administrative leadership) in maintaining human capital. The hypothesis that has been tested shows a statistically significant impact on the challenges facing human resources in maintaining human capital. These results are due to the fact that private hospitals are employing human resources to provide health services of the highest possible quality. This result is attributed to the interest of the hospital departments in human resources that contribute to their competitiveness to face competition at the local and regional levels. This result is explained by the increasing competition between them as a natural result of the increasing number of hospitals, health centers and the emergence of a modern quality of health services which necessitates hospitals to improve their strengths through the training of their staff and through the possession of a qualified personnel. Also reducing turnover rates, as well as increasing employee innovation to increase its ability to achieve excellence and achieve the competitiveness it seeks. The results are also attributed to the awareness of hospitals' administrations about the importance of human resource management practices in providing capabilities. The results are consistent with the study of (Sakka, 2013), which considers that the process of delegating authorities to workers and giving them a space of decision-making drives them to work, and affects their productivity positively as well as, there warding system to increase productivity and improve performance. The PAS needs to be more transparent in order to achieve justice and excellence for employees.

Incentives affect the maintenance of human capital; this result is attributed to increased attention to employees' issues through increased wages, incentives, bonuses and comprehensive health insurance, which in turn increases satisfaction and stability, thus improving patient service (Khudair, 2014), which found that incentives of both types: material incentives and business-related incentives have a direct positive impact on all dimensions of regulatory justice, where financial incentives interpret distributive justice to a higher degree, while Explain ing the dialogue Job-related procedural and justice; justice is more interactive. The impact of the incentives in the current study differed with the study of (Kvist ,2012), which found that the existing incentive system was not appropriate to the environment in the organizations within Sweden, nor was it compatible with the incentive system offered in Swedish organizations.

There is an impact on the pressures of working in the maintenance of human capital, and this is because the interest in reducing the pressure of work, contributes to the creation of organizational loyalty, and a sense of belonging to the employee through the attention of the department with regard to all workers and to identify strengths. The results were compared with (Melhem ,2007), which found a statistically significant relationship between work pressures, the tendency of individuals in companies looking for job dropout, and there is a clear tendency among individuals in the companies that are left to work.

The impact of the administrative leadership in the preservation of human capital in private hospitals in Irbid governorate can be attributed to the improvement and activation of channels of communication between hospital management and staff by listening to their suggestions and engaging them in setting some goals (management by objectives) (Masood, SA, 2006), which found that the transformational driving style is one of the most important means of creating the leadership needed to improve, develop and improve the performance of the hospital. The performance of the 
organization, that has a transformational leadership style helps to develop organizational culture, which is reflected positively on the performance of the staff level. Masood, S.A (2006), which found that the mode of transformational leadership is one of the most important means to create the leadership needed to improve the overall performance of the organization.

\section{Implications and Future Direction}

The model of the study illustrates how the variables affected each other. The management level can maximize resources in their organization. Basically, our main variables research proposed the challenges of human resources, human capital. The result of this research was presented as a new framework for guiding the implementation of the strategy to preserve human capital. While a number of research has been proposed to develop links between human capital and human resources practices, and although there are many studies in this area, a few tools have been developed that have been verified in best practices and addressed the challenges of maintaining human capital, Given the importance of strategic alignment of these factors has a direct positive impact on the performance of business, many of them must take into account the realities of strategic alignment in the field of human capital preservation.

In the future, private hospitals should seek to reduce the challenges facing their human resources by increasing attention to better addressing the challenges facing human resource through increased wages, incentives, rewards, comprehensive health insurance and an adequate work environment which leads to a cycle of career stability by increasing their satisfaction and, thus excellence in the service of patients, thus achieving the competitiveness of the hospital.

Improving the communication channels between the hospital management and the employees by listening to their suggestions and engaging them in goal development (management by objectives) to sharpen their goals and improve their performance efficiency, which will increase the level of the overall performance.

The results of this study should be spread to all hospitals in Jordan and the Middle East and should be used to guide researchers to study other challenges that human resources may face, so organizations can improve and maintain their human resources.

\section{References}

Abdel Baqi, S., Din M., (2004), Effective Behavior in Organizations, Alexandria: University Press.

Abualoush, S. H., Obeidat , A. M., Tarhini, A., Masa'deh ,R., Al-Badi A.,(2018) The role of employees' empowerment as an intermediary variable between knowledge Management and information systems on employees' performance. VINE Journal of Information and Knowledge Management Systems,Vol. 48 No. 2, pp. 217-237

Al Kaabi, N., Saleh, M., (2003). Personnel Management: Applied Approach. Baghdad

Al katatneh, S. \& Al medanat, R., (2011) The Impact of Family Formation and Psychological Stress on Psychological Alienation among Grade 10 Grade Students in Karak Governorate, Mu'tah Research and Studies, Vol. 26, p.3.

Al-Dosari, H. M., (2013), Leadership Patterns and Job Satisfaction in the College of Technology in AlKharj from the Employees' Point of View. Unpublished Master Thesis, Naif Arab University for Security Sciences, Riyadh. 
Al-Fateh, N. B. S., (2001), organizational culture and its relation to job satisfaction in the security services. Unpublished Master Thesis, Naif Arab University for Security Sciences, Riyadh.

Al-Obeidi, B. M. K., Ahmed, S. \& Al-Azzawi, K., (2010) "Organizational creativity and its impact on improving the quality of the product: a study of the views of a sample of employees in the General Company for Electrical Industries". Journal of Administration and Economics, Volume 4, Issue 8

Al-Sakka, A. M. (2013) Psychological motivations and incentives and their relation to the performance of workers in the field of banking sector in the Gaza Strip. Master Thesis, Islamic University, Gaza

Altwaijri, B. I. (2007), Problems Facing Practitioners of Nursing in the Work Environment, Unpublished Master Thesis, King Saud University, Riyadh

Ashton, R. (2005), study: Intellectual Capital and ialue Creation: A Review, Jowrnal of Accounting literature, vol. (24).

Barkawi, Wa. B. (2013). Concept, Functions and Strategies, Jordan: Dar El Yazouri Hamada Publishing and Distribution.

Bhansi, F. (2011). Job Satisfaction of Employees from a Social Work Perspective, Egypt: Dar El Wafaa Printing \& Publishing.

Buhaz, M., \& Marzouki, R. (2009). Administrative Leadership and its relation to administrative creativity. Research paper presented to the International Forum, Boudiaf University, Algeria.

Dissler, G. (2003). Human Resource Management, (9thed), New jetsey: Prenticettall.

Gad Al rab, S. M. (2005). Human Resources Management Advanced Topics and Research, Cairo: AlAshry Press.

Halwani, A. B. (2001). Factors that may cause faculty members at King Saud University to drop out of the university. Master 's thesis unpublished, King Saud University, Riyadh.

Hamayan, A. (2007), Working pressures faced by nurses in the Saudi governmental health sector. Unpublished Master Thesis, Yarmouk University, Jordan.

Hamzawy, M. S. (2007). Administrative and Organizational Behavior in Civil and Security Organizations, Riyadh: Al-Shaari Library.

Harem, H. (2013). Behavior of individuals and groups in business organizations, Jordan. Alhamid Publishing.

Hassan, A. A. (2009). Distinguished Human Resource Management Distinctive, Mansoura: Modern Library.

Hassan, R. (2005). Strategic Planning and Human Resources Development, Alexandria: University House.

Irtaimeh, H. J., Obeidat., A. M., Abualloush, S. H., Khaddam, A. A. (2016) Impact of Business Intelligence on Technical Creativity: A Case Study on AlHekma Pharmaceutical Company, European Scientific Journal , vol.12, No.28,PP,502-519

Khudair, B. Z. N. (2014) Role of Incentives in Raising Organizational Justice. Case Study: National Institute of Inspection ENAFOR - HassiMessaoud, MA - University of Mohamed Khaydar

Maani, A., Jaradat, N., Saleh, A. \& Erekat, A. (2011). Contemporary Administrative Issues, Jordan: Dar Wael Publishing and Distribution. 
Malkawi, N. M.M., Baniata, M. I., Obeidat, A. M. (2017) The Impact of E-Government Applications on Decision-Making Effectiveness: Case Study at Jordanian Ministry of Interior-Jordan, International Review of Management and Business Research, Vol. 6 Issue.1, pp 180-191.

Masood, S. A. (2006). Transformational leadership and organizational culture: the situational strength perspective. Proceedings of the Institution of Mechanical Engineers, Part B: Journal of Engineering Manufacture, 220(6), pp. 941-949

Melhem, W. A. (2007): Work pressure and its relation to employee attitudes toward career dropout: Survey study of security guards working in security security companies in Riyadh, Master Thesis, Naif Arab University for Security Sciences.

Motaher, M. (2005). Challenges Facing Higher Education in the Republic of Yemen Reality and Future Vision. Research submitted to the National Information Center, Yemen.

Obeidat A. M. \& Otibi, G. A. (2015) The Impact of Knowledge Sharing Tools on Levels of Organizational Learning (Field Study on Jordanian Commercial Banks) Australian Journal of Basic and Applied Sciences, 9(5) March 2015, Pages: 253-267

Obeidat, A. M., Abualoush, S. H., Irtaimeh,H. J., Khaddam, A. A.,\& Bataineh, K. A. (2018) The role of organizational culture in enhancing the human capital applied study on the social security corporation, Int. J. Learning and Intellectual Capital, Vol. 15, No. 3,pp 258-276.

Obeidat, B., Tarhini, A., Masa'deh, R., and Aqqad, N. (2017), The impact of intellectual capital on innovation via the mediating role of knowledge management: a structural equation modelling approach, Int. J. Knowledge Management Studies, Vol,8.No 3-4, pp. 273-298

Reda, H. H. (2010). Communication Skills and Administrative Leadership, Palestine: Dar Al Rayah.

Safhi, M. A. (2011), leadership styles and their relationship to the management of the organizational conflict in the private organizations in Riyadh.

Salmi, A. (2008). Human Resources Management Strategic Perspective, Cairo: Dar Al-Ghareeb Press.

Sekaran, U. (2013). Research methods for business: A skill-building approach. 4th Edn., John Wiley and Sons, Inc

Sultan, M. S. (2003). Organizational Behavior, Egypt: New University Publishing House.

Tamasini, M. (2015), The Relationship of Job Stress to Job Satisfaction, Unpublished Master Thesis, Al-Shaheed University Hama Lakhdar Al-Wadi.

TarjaKvist, R. M., Pirjo P., Hannele T., Merja M., \& Katri, V.-J., (2012) The Job Satisfaction of Finnish Nursing Staff: The Development of a Job Satisfaction Scale and Survey Results ,Nursing Research and Practice;(10):1-11.

Tawim, N. F. (2005), levels of work pressure and ways to confront them in the security services. Unpublished Master Thesis, Naif Arab University for Security Sciences, Riyadh.

United Nations Development Program: Arab Human Development Report 2003, p. 95.

Yousef, M. H. (2008), the stimulus and its impact on achieving job satisfaction among workers in the industrial sector in the city industrial facilities in Makkah, unpublished Master Thesis, British Arab Academy for Higher Education. 